\title{
PENGEMBANGAN MATERI SAINS SD/MI DENGAN PENGGUNAAN MODUL DALAM PENDEKATAN CONTEXTUAL TEACHING AND LEARNING
}

\author{
Syahru Ramadhan \\ Institut Agama Islam (IAI) Muhammadiyah Bima \\ Email : syahrupgmi05@gmail.com
}

\begin{abstract}
Abstrak
Dalam artikel ini menjelaskan bahwa pembelajaran Sains menuntut siswa tidak hanya sekedar menghafal fakta tetapi juga pengaplikasiannya dalam kehidupan nyata. Pada pembelajaran IPA materi gaya dan gerak, anak dituntut untuk berinteraksi langsung dengan lingkungan termasuk pada kegiatan sehari-hari anak sehingga pembelajaran tersebut menjadi lebih bermakna. tercapainya tujuan pembalajaran sains di sekolah dasar, salah satunya menggunakan pendekatan pembelajaran dan bahan ajar yang tepat. Salah satu pendekatan yang sesuai yaitu menggunakan pendekatan Contextual Teaching and Learning (CTL)dan modul yang kami gunakan sebagai bahan ajar. Pendekatan pembelajaran Contextual Teaching and Learning (CTL) merupakan konsep belajar yang membantu guru mengaitkan antara materi yang diajarkan dengan situasi dunia nyata siswa dan mendorong siswa membuat hubungan antara pengetahuan yang dimilikinya dengan penerapannya dalam kehidupan mereka sebagai anggota keluarga dan masyarakat.
\end{abstract}

Kata Kunci : Materi Sains MI, Modul, CTL

\section{PENDAHULUAN}

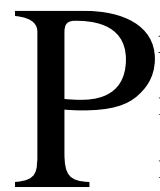

roses pembelajaran di kelas pada kurikulum 2013 sudah mulai menerapkan pembelajaran aktif, yakni pembelajaran yang melibatkan siswa untuk berpartisipasi aktif dalam proses pembelajaran. Tidak hanya guru yang menjadi pusat belajar di kelas, melainkan siswa juga ikut aktif dalam kegiatan belajar mengajar di kelas tersebut. Hal tersebut sesuai dengan standar proses yang tertuang di Permendikbud Nomor 22 Tahun 2016.

Pada standar proses yang tertuang di Permendikbud Nomor 22 Tahun 2016, juga dijelaskan bahwa guru bukanlah satu-satunya sumber belajar yang diperoleh oleh siswa, melainkan ada banyak sumber belajar. Misalnya, dari internet, buku paket, handout, modul pembelajaran, dan sebagainya. Pada kurikulum 2013, siswa lebih ditekankan untuk belajar 
secara mandiri, aktif, ditekankan untuk mencari tahu. Sehingga guru harus pandai-pandai memberikan stimulus atau cara-cara yang bisa melibatkan anak agar anak bisa lebih muncul rasa ingin tahunya.

Salah satu sumber belajar yang dengannya siswa dapat belajar secara mandiri, adalah modul. Pengembangan modul sangat diperlukan, karena dengan adanya modul diharapkan siswa bisa belajar secara mandiri, serta dapat memunculkan rasa ingin tahu siswa itu sendiri. Rasa ingin tahu siswa bisa dibangun dengan mengadakan percobaan-percobaan sederhana. Oleh karena itulah, kami bermaksud akan mengembangkan suatu modul pembelajaran IPA.

\section{TINJAUAN TEORITIS}

\section{Hakikat Sains}

Sains merupakan bagian dari kehidupan kita dan kehidupan kita merupakan bagian dari sains. Belajar sains bukan hanya untuk memahami konsep-konsep ilmiah dan aplikasinya dalam masyarakat, melainkan juga untuk mengembangkan berbagai nilai. Sains dalam arti sempit sebagai disiplin ilmu dari physical sciences dan life sciences. Yang temasuk physical sciences adalah ilmu-ilmu astronomi, kimia, geologi, mineralogi, meteorologi, dan fisika: sedangkan life sciences meliputi biologi (anatomi, fisiologi, zoologi, citologi dan seterusnya).

James conant, mendefenisikan sains sebagai "suatu deretan konsep serta skema konseptual yang berhubungan satu sama lain, dan yang tumbuh sebagai hasil eksperimental dan observasi, serta berguna untuk diamati dan dieksperimentasikan lebih lanjut. Kemudian A.N. Whitehead menyatakan bahwa sains dibentuk karena pertemuan dua orde pengalaman. Orde pertama didasarkan kepada hasil observasi terhadap gejala/fakta (orde observasi), dan kedua didasarkan pada konsep -konsep manusia mengenai alam (orde konseptual) (Usman Samatowa, 2010).

Chiappetta mengutarakan bahwa hakikat sains adalah sebagai $a$ way of thingking (cara berfikir), a way of investigating (cara penyelidikan), dan a body of knowledge (sekumpulan pengetahan). Sebagai cara berfikir, Sains merupakan aktivitas mental (berfikir) orangorang yang bergelut dalam bidang yang dikaji. Para ilmuan berusaha mengungkap, menjelaskan serta menggambarkan fenomena alam. Ide-ide 
dan penjelasan suatu gejala alam tersebut disusun dalam pikiran. Kegiatan mental tersebut didorong oleh rasa ingin tahu (curiousity) untuk memahami fenomena alam.

Menurut Hungerford, Volk dan Ramsey, sains adalah (1) proses memperoleh informasi melalui metode empiris (empirical method); (2) informasi yang diperoleh melalui penyelidikan yang telah ditata secara logis dan sistematis, (3) suatu kombinasi proses berpikir kritis yang menghasilkan informasi yang dapat dipercaya dan valid.Berdasarkan tiga defenisi tersebut, Hungerford, Volk \& Ramsey menyatatakan bahwa sains mengandung dua elemen utama, yaitu: proses dan produk yang saling mengisi dalam derap kemajuan dan perkembangan sains. Sains sebagai suatu proses merupakan rangkaian kegiatan ilmiah atau hasil-hasil observasi terhadap fenomena alam untuk menghasilkan pengetahuan ilmiah (scientific knowledge) yang lazim disebut produk sains

Dari berbagai ide mengenai pembelajaran sains, kegiatan dikelas di kelola menjadi serupa dengan apa yang sesungguhnya dilakukan para ilmuan dalam percobaan mereka, namun dalam situasi yang berbeda. Para ilmuan melakukan berbagai percobaan untuk menghasilkan berbagai teori, sedangkan anak melakukan kegiatan serupa untuk memahami dan memahami konsep baru atau menguji berbagai ide.

Menurut Bambang Sumintono terdapat tiga faktor utama pembelajaran sains di sekolah, yaitu dapat berbentuk: (1) produk dari sains, yaitu pemberian berbagai pengetahuan ilmiah yang dianggap penting untuk diketahui siswa (hard skills), dan (2) sains sebagai proses, yang berkonsentrasi pada sains sebagai metode pemecahan masalah untuk mengembangkan keahlian siswa dalam memecahkan masalah (hard skills dan soft skills); (3) pendekatan sikap dan nilai ilmiah serta kemahiran insaniah (soft skills) (Siti Fatonah dan Zuhdan K.Prasetyo, 2014).

\section{Pembelajaran Sains di SD/MI}

IPA (sains) berupaya membangkitkan minat manusia agar mau meningkatkan kecerdasan dan pemahaman tentang alam seisinya yang penuh dengan rahasia yang tak habis-habisnya. Adapun pengetahuan itu sendiri artinya segala sesuatu yang diketahui oleh manusia. Jadi secara 
singkat IPA adalah pengetahuan yang rasional dan objektif tentang alam semesta dengan segala isinya. Ilmu pengetahuan alam merupakan terjemahan kata-kata dalam bahasa inggris yaitu natural science, artinya ilmu pengetahuan alam (IPA).

Pada tingkat sekolah dasar, anak perlu diberi kesempatan untuk berlatih keterampilan-keterampilan proses IPA. Sehingga harus ada modifikasi keilmuan IPA sesuai dengan tahap perkembangan kognitifnya. Keterampilan proses sains didefenisikan oleh Paolo dan Marten adalah: (1) mengamati, (2) mencoba memahami apa yang diamati, (3) mempergunakan pengetahuan baru untuk memperkirakan apa yang terjadi, (4) menguji perkiraan-perkiraan tersebut untuk mengetahui apakah perkiraan-perkiraan itu benar. Selanjutnya Paolo dan Marten juga menegaskan bahwa dalam IPA tercakup juga coba-coba dan melakukan kesalahan, gagal dan mencoba lagi (Usman Samatowa, 2010).

Jadi pembelajaran IPA di sekolah dasar hendaknya membuka kesempatan untuk memupuk rasa ingin tahu anak didik secara alamiah. Hal ini akan membantu mereka mengembangkan kemampuan bertanya dan mencari jawaban berdasarkan atas bukti serta mengembangkan cara berpikir ilmiah. Fokus program pengajaran IPA di sekolah dasar hendaknya ditujukan untuk memupuk minat dan pengembangan kemampuan anak didik terhadap dunia mereka di mana mereka hidup. Perlunya IPA diajarkan di sekolah dasar, (Usman Samatowa, 2010) yaitu:

1. Bahwa IPA bermanfaat bagi suatu bangsa, karena IPA merupakan dasar teknologi, sering disebut sebagai tulang punggung pembangunan. Pengetahuan dasar untuk teknologi adalah IPA yang cukup luas mengenai berbagai gejala alam.

2. Jika IPA diajarkan sesuai cara yang tepat, maka IPA merupakan suatu mata pelajaran yang memberikan kesempatan berpikir kritis.

3. Jika IPA diajarkan melalui percobaan-percobaan yang dilakukan sendiri oleh anak, maka IPA tidaklah merupakan mata pelajaran yang sifatnya hafalan belaka.

4. Mata pelajaran ini mempunyai nilai-nilai pendidikan yaitu mempunyai potensi yang dapat membentuk kepribadian anak secara keseluruhan. 
Menurut permendiknas No. 22 tahun 2006, kompetensi dalam pembelajaran sains SD/MI, dapat dipilahkan menjadi lima, yaitu (1) menguasai pengetahuan tentang berbagai jenis dan perangai lingkungan alam dan lingkungan buatan dalam kaitan dengan pemanfaatannya bagi kehidupan sehari-hari; (2) mengembangkan keterampilan proses sains; (3) mengembangkan wawasan, sikap dan nilai-nilai yang berguna bagi siswa untuk meningkatkan kualitas kehidupan sehari-hari; (4) mengembangkan kesadaran tentang keterkaitan yang saling mempengaruhi antara kemampuan sains dan teknologi dengan keadaan lingkungan serta pemanfaatannya bagi kehidupan nyata sehari-hari; dan (5) mengembangkan kemampuan siswa untuk menerapkan iptek serta keterampilan yang berguna dalam kehidupan sehari-hari maupun untuk melanjutkan pendidikannya ketingkat yang lebih tinggi (Siti Fatonah dan Zuhdan K.Prasetyo, 2014).

Untuk mencapai tujuan dan memenuhi pendidikan IPA di sekolah dasar, maka dibutuhkan suatu pendekatan yang digunakan dalam proses belajar mengajar IPA antara lain ialah:

1. Pendekatan lingkungan,

2. Pendekatan keterampilan proses,

3. Pendekatan inkuiri (penyelidikan), dan

4. pendekatan terpadu (terutama di SD)

Berdasarkan beberapa pendekatan tersebut, maka kami menggunakan pendekatan Contextual Teaching and Learning (CTL) yang sebagian dari keempat pendekatan tersebut terangkum dalam pendekatan Contextual Teaching and Learning (CTL). Berikut ini akan dijelaskan secara rinci tentang pendekatan Contextual Teaching and Learning (CTL).

\section{Pendekatan Contextual Teaching and Learning (CTL)}

Pembelajaran yang berorientasi pada penguasaan materi dianggap gagal menghasilkan peserta didik yang aktif, kreatif dan inovatif. Peserta didik berhasil "mengingat" jangka pendek, tetapi gagal dalam membekali peserta didik memecahkan persoalan dalam kehidupan jangka panjang. Oleh karena itu, perlu ada perubahan pendekatan pembelajaran yang lebih 
bermakna sehingga dapat membekali peserta didik dalam menghadapi permasalahan hidup yang dihadapi sekarang maupun yang akan datang. Pendekatan pembelajaran yang cocok untuk hal di atas adalah pendekatan pembelajaran Contextual Teaching and Learning (CTL).

Pendekatan pembelajaran Contextual Teaching and Learning (CTL) merupakan konsep belajar yang membantu guru mengaitkan antara materi yang diajarkan dengan situasi dunia nyata siswa dan mendorong siswa membuat hubungan antara pengetahuan yang dimilikinya dengan penerapannya dalam kehidupan mereka sebagai anggota keluarga dan masyarakat. Dengan konsep itu, hasil pembelajaran diharapkan lebih bermakna bagi siswa. Proses pembelajaran berlangsung alamiah dalam bentuk kegiatan siswa bekerja dan mengalami, bukan mentransfer pengetahuan dari guru ke siswa (Zainal Aqib, 2013).

Johnson (dalam Syaiful Sagala) mengatakan Contextual Teaching and Learning (CTL) adalah suatu sistem yang merangsang otak untuk menyusun pola-pola yang mewujudkan makna. Pendekatan pembelajaran Contextual Teaching and Learning (CTL) adalah suatu sistem pengajaran yang cocok dengan otak yang menghasilkan makna dengan menghubungkan muatan akademis dengan konteks dari kehidupan seharihari peserta didik. Konteks biasanya disamakan dengan lingkungannya, yaitu dunia luar yang dikomunikasikan melalui panca indera, ruang yang digunakan setiap hari (Syaiful Sagala, 2010).

Contextual Teaching and Learning (CTL) mempunyai 6 (tujuh) asas yang menjadi landasan filosofis. Menurut Elaine B. Johnson (dalam Suyadi) menjelaskan bahwa asas-asas tersebut sering juga disebut sebagai komponen-komponen Contextual Teaching and Learning (CTL). Asasasas tersebut adalah sebagai berikut (Syaiful Sagala, 2010):

a) Inkuiri

Inkuiri merupakan proses pembelajaran yang didasarkan pada pencarian dan penemuan melalui berpikir secara sistematis. Pengetahuan bukanlah sejuta fakta hasil dari mengingat, tetapi hasil dari proses menemukan sendiri. Dengan demikian, dalam proses perencanaan, guru bukanlah mempersiapkan sejumlah materi yang 
harus dihafal dan dipahami, tetapi merancang pembelajaran yang memungkinkan peserta didik dapat menemukan sendiri materi yang harus dipahami tersebut.

b) Bertanya (Questioning)

Belajar pada hakikatnya adalah bertanya dan menjawab pertanyaan. Bertanya bukan berarti tidak tahu, demikian pula dengan menjawab bukan berarti telah paham. Sebab, bertanya dapat dipandang sebagai refleksi dari keingintahuan setiap individu, sedangkan menjawab pertanyaan dapat dipandang sebagai cerminan kemampuan seseorang dalam berpikir. Dalam proses pembelajaran melalui Contextual Teaching and Learning (CTL), guru tidak menyampaikan informasi begitu saja, tetapi memancing agar peserta didik dapat menemukan jawabannya sendiri. Oleh karena itu, peran bertanya sangat penting, sebab melalui pertyanyaan-pertanyaan dari peserta didik, guru dapat membimbing dan mengarahkan mereka untuk menemukan setiap materi yang dipelajarinya.

Dalam pembelajaran yang produktif, kegiatan bertanya dan menjawab dapat dilakukan dengan cara-cara sebagai berikut: a) Menggali informasi, khususnya kemampuan dasar peserta didik dalam penguasaaan materi pelajaran yang akan maupun yang sedang dibahas; b) Membangkitkan motivasi peserta didik utnuk belajar lebih sungguh-sungguh; c) Merangsang keingintahuan peserta didik terhadap topic-topik tertentu; d) Memfokuskan peserta didik pada sesuatu yang diinginkannya; e) Membimbing peserta didik untuk menemukan atau menyimpulkan materi pembahasan.

c) Masyarakat Belajar (Learning Community)

Elaine B. Johnson (dalam Suyadi) menerangkan bahwa, masyarakat belajar dalam Contextual Teaching and Learning (CTL) adalah kerjasama atau belajar bersama dalam sebuah masyarakat atau kelas-kelompok. Kerjasama atau belajar bersama tersebut dapat dilakukan dalam berbagai bentuk, baik dalam belajar kelompok secara formal, maupun dalam lingkunagn yang terjadi secra alamiah. Hasil belajar dapat diperoleh dari sharing dengan orang lain, antar 
teman atau antar kelompok. Inilah hakikat dari masyarakat belajar, masyarakat yang saling berbagi pengalaman, informasi dari pengetahuan. Pemodelan (Modelling)

Asas modelling adalah proses pembelajaran dengan memperagakan sesuatu sebagai contoh yang dapat ditiru oleh setiap peserta didik. Misalnya, guru biologi memberikan contoh bagaimana cara mencangkok tanaman, dan seterusnya. Proses modeling tidak terbatas pada guru saja, tetapi dapat juga memanfaatkan peserta didik yang dianggap memiliki kemampuan. Misalnya, peserta didik yang bisa menendang bola dapat disuruh untuk memberikan contoh pada peserta didik yang lain.

d) Refleksi (reflection)

Refleksi adalah proses pengendapan pengetahuan dan pengalaman yang dilakukan dengan cara mengurutkan kembali kejadian-kejadian atau peristiwa pembelajaran yang telah diprosesnya. Melalui proses refleksi, pengelaman belajar itu akan dimasukkan dalam struktur kognitif peserta didik, yang pada akhirnya menjadi bagian dari pengetahuan. Tidak menutup kemungkinan mealui proses refleksi tersebut, peserta didik akan memperbarui pengetahuan yang telah dibentuknya atau menambah khazanah pengetahuan mereka.

Dalam proses pembelajaran Contextual Teaching and Learning (CTL), setiap akhir pembelajaran, guru memberikan kesempatan kepada peserta didik untuk "merenung" atau mengingat kembali apa yang telah dipelajarinya. Dengan kata lain, guru membiarkan peserta didik secara beabs untuk menafsirkan pengalamannya sendiri, sehingga ia dapat menyimpulkan tentang pengalaman belajarnya.

e) Penilaian Nyata (Authentic Assessment)

Penilaian nyata adalah proses yang dilakukan guru untuk mengumpulkan informasi tentang perkembangan belajar yang dilakukan peserta didik. Penilaian ini diperlukan untuk mengetahui apakah peserta didik benar-benar atau tidak, memahami atau tidak, 
menguasai atau tidak, apakah pengalamn belajar peserta didik memiliki pengaruh yang positif terhadap perkembangan, baik intelektual maupun mental peserta didik. Penilaian yang autentik dilakuakn secara terintegrasi dengan proses pembelajaran. Penilaian ini dilakukan secara kontinu selama proses pembelajaran berlangsung. Oleh karena itu, penilaian difokuskan pada proses belajar bukan pada hasil belajar.

Sebelum membahas jauh tentang bagaimana penggunakaan pendekatan Contextual Teaching and Learning (CTL) dalam memahami materi yang ada pada tingkat sekolah dasar maka akan dijelaskan dahulu tentang bahan ajar.

\section{Bahan Ajar}

Bahan atau materi ajar adalah segala sesuatu yang hendak dipelajari dan dikuasai para siswa, baik berupa pengetahuan, keterampilan, maupun sikap melalui kegiatan pembelajaran. Bahan pembelajaran merupakan sesuatu yang disajikan guru untuk diolah dan dipahami oleh siswa dalam rangka mencapai tujuan-tujuan pembelajaran yang telah ditetapkan. Bahan ajar merupakan salah satu sumber belajar dalam bentuk konsep, prinsip, defenisi, gugus atau konteks, dan maupun fakta, proses, nilai, kemampuan dan keterampilan (Mohammad Syarif Sumantri, 2015).

Bahan ajar adalah segala bentuk bahan yang digunakan untuk membantu guru dalam melaksanakan proses pembelajaran. Bahan ajar merupakan alat dan teks yang diperlukan guru dalam proses perencanaan dan implementasi pembelajaran. Bahan ajar adalah seperangkat materi yang disusun secara sistematis yang bisa membantu guru atau instruktur dalam melaksanakan kegiatan pembelajaran dan digunakan oleh siswa untuk belajar.

Berdasarkan beberapa pengertian di atas dapat disimpulkan bahan ajar adalah seperangkat bahan yang berisi materi pembelajaran yang disusun secara sistematis yang digunakan oleh guru dalam melaksanakan kegiatan belajar mengajar serta digunakan oleh siswa untuk belajar. Siswa tinggal berhadapan dengan bahan pembelajaran yang terdokumentasi secara apik melalui informasi yang konsisten. Hal ini dapat memberikan 
kesempatan belajar menurut kecepatan masing-masing peserta didik. Jadi pentingnya bahan pembelajaran mencakup tiga elemen penting, yakni: (1) sebagai representasi kajian guru, dosen atau instruktur; (2) sebagai sarana pencapaian standar kompetensi, kompetensi dasar, atau tujuan pembelajaran; dan (3) sebagai optimalisasi pelayanan terhadap peserta didik (Muhammad Yaumi, 2013).

Bahan ajar sendiri menurut Abdul Majid terdiri dari beberapa jenis, yaitu:

1. Bahan cetak (printed) antara lain handout, modul, buku, lembar kerja siswa, dan sebagainya.

2. Bahan ajar dengar (audio) seperti kaset, radio, dan compact disk audio.

3. Bahan ajar pandang dengar (audio-visual) seperti televisi, video, film, dan sebagainya.

4. Bahan ajar interaktif seperti compact disk interaktif (Abdul Majid, 2008).

\section{Konsep Modul}

Modul merupakan salah satu jenis bahan ajar yang digunakan oleh guru dalam bentuk cetak. Modul diartikan sebagai suatu buku yang ditulis dengan tujuan agar siswa mampu belajar secara mandiri tanpa membutuhkan bantuan dari guru. Pada pengertian lain, modul diartikan sebagai seperangkat bahan ajar yang disajikan secara sistematis, sehingga pengguna modul tersebut bisa menggunakan modul tersebut tanpa fasilitator (Andi Prastowo, 2012). Bahasa, pola, serta sifat kelengkapan lainnya yang ada di modul diatur sehingga seolah-olah merupakan bahasa guru yang sedang memberikan pelajaran ke siswa-siswanya. Pengajar tidak secara langsung memberi pelajaran atau mengajarkan sesuatu kepada para siswanya secara tatap muka, melainkan modul ini (Direktorat Tenaga Kependidikan, 2008).

Surahman, menjelaskan bahwa modul merupakan satuan program pembelajaran terkecil yang dapat dipelajari oleh siswa secara individu, setelah menyelesaikan satu satuan modul, siswa dapat melangkah ke satuan modul berikutnya(Andi Prastowo, 2008).

Modul pembelajaran memiliki beberapa fungsi (Andi Prastowo, 2012), yakni: 
1) Bahan ajar mandiri. Maksudnya, dengan adanya modul pembelajaran di kelas berfungsi untuk meningkatkan kemauan siswa untuk belajar secara mandiri.

2) Pengganti fungsi guru. Modul sebagai bahan ajar harus mampu menjelaskan materi pembelajaran dengan baik, serta dapat dimengerti oleh siswa.

3) Sebagai alat evaluasi. Modul dapat diguanakan sebagai alat evaluasi yang dapat digunakan sendiri oleh siswa, sehingga siswa dapat mengukur penguasaannya terhadap suatu materi yang ada di modul.

Adapun tujuan dari pembuatan modul adalah sebagai berikut (Direktorat Tenaga Kependidikan, 2008):

1) Memperjelas dan mempermudah penyajian pesan agar tidak terlalu bersifat verbal.

2) Mengatasi keterbatasan waktu, ruang, dan daya indra.

3) Dapat digunakan secara tepat dan bervariasi, seperti untuk meningkatkan motivasi dan gairah belajar.

4) Memungkinkan siswa untuk dapat mengukur atau mengevaluasi sendiri hasil belajarnya.

Terdapat empat langkah yang harus dipahami sebelum menyusun modul, yaitu melakukan analisis kurikulum, penentuan judul modul, dan penulisan modul. Penjelasan secara rinci mengenai keempat langkah tersebut, yakni:

a. Analisis Kurikulum

Tahap pertama yang harus dilakukan yakni menganalisis kurikulum yang berlaku untuk menentukan materi yang butuh untuk dibuatkan modul. Analisis tersebut meliputi(Direktorat Tenaga Kependidikan, 2008):

1) Menetapkan kompetensi yang terdapat dalam garis-garis besar program pembelajaran yang akan disusun menjadi modul

2) Mengidentifikasi dan menentukan pengetahuan, sikap, dan keterampilan yang disyaratkan

3) Kegiatan ini dilaksanakan pada awal pengembangan modul

b. Menentukan Judul Modul 
Setelah melakukan analisis terhadap kurikulum, langkah berikutnya adalah menentukan judul modul yang akan disusun. Judul tersebut harus mengacu pada kompetensi dasar atau materi pokok yang ada di kurikulum. Satu kompetensi bisa dijadikan menjadi satu judul besar jika tidak terlalu besar cakupan materinya.

c. Penulisan Modul

Dalam penyusunan modul, terdapat lima hal penting yang harus dilakukan, yakni (Andi Prastowo, 2012):

1) Merumuskan kompetensi dasar

Rumusan kompetensi dasar merupakan salah satu aspek yang harus dikuasai oleh siswa. Kompetensi dasar tersebut diambil dari kurikulum yang berlaku saat ini.

2) Menentukan alat evaluasi atau penilaian

Dalam menentukan evaluasi atau penilaian ini berisi pertanyaanpertanyaan atau tes yang digunakan untuk mengetahui tingkat keberhasilan peserta didik dalam menguasai suatu kompetensi dasar. Evaluasi dapat disusun setelah ditentukan kompetensi dasar yang akan dicapai, sebelum menyusun materi dan lembar kerja atau tugas-tugas yang harus dikerjakan oleh siswa. Hal tersebut bertujuan agar evaluasi yang dikerjakan benar-benar sesuai dengan apa yang dikerjakan oleh siswa.

3) Menyusun materi

Materi yang ada di dalam modul sangat bergantung dengan kompetensi dasar yang akan dicapai. Materi yang ada di dalam modul sebaiknya memiliki referensi dari berbagai sumber, misalnya buku, internet, majalah, atau jurnal. Kita dapat menuliskan referensi dari materi tersebut agar siswa dapat membaca lebih jauh tentang materi tersebut.

\section{SIMPULAN}

Pada pembelajaran IPA materi gaya dan gerak, anak dituntut untuk berinteraksi langsung dengan lingkungan termasuk pada kegiatan seharihari anak sehingga pembelajaran tersebut menjadi lebih bermakna. Hal ini menunjuikan bahwa pembelajaran dalam kurikulum 2013 berbasis 
integrasi menuntut siswa untuk lebih berperan aktif dalam proses pembelajaran. Dengan melaihat kapasitas keilmuan yang dimiliki oleh peserta didik maka guru memberikan pemahaman yang utuh tetang materi yang disampaikan yaitu dengan mengajak peserta didik untuk berpikir kongkrit dengan melihat secara langsung materi yang sedang dipelajari. Agar tercapainya tujuan pembalajaran sains di sekolah dasar, salah satunya menggunakan pendekatan pembelajaran dan bahan ajar yang tepat. Salah satu pendekatan yang sesuai yaitu menggunakan pendekatan Contextual Teaching and Learning (CTL)dan modul yang kami gunakan sebagai bahan ajar. Pendekatan pembelajaran Contextual Teaching and Learning (CTL) merupakan konsep belajar yang membantu guru mengaitkan antara materi yang diajarkan dengan situasi dunia nyata siswa dan mendorong siswa membuat hubungan antara pengetahuan yang dimilikinya dengan penerapannya dalam kehidupan mereka sebagai anggota keluarga dan masyarakat.

Oleh karena demikian, guru MI yang kreatif dan inovatif adalah mampu menerapkan berbagai strategi dan metode pembelajaran agar siswa dapat memahami setiap materi yang disampaikan. Penarapan Pendekatan Contextual Teacing and Learning dalam pembelajaran sains di MI merupakan salah satu bagian dari pola pembelajaran yang dilakukan guru supaya peserta didik dapat mengembangkan kreatifas proses sains sesuai standar keilmiahan.

\section{DAFTAR PUSTAKA}

Aqib, Zainal. Model-Model, Media dan Strategi Pembelajaran Kontekstual (inovatif). Bandung: CV Yrama Widya. 2013

Direktorat Tenaga Kependidikan.Penulisan Modul. Jakarta: Depdiknas. 2008 Fatonah, Siti dan Zuhdan K.Prasetyo. Pembelajaran Sains. Yogyakarta: Ombak (Anggoka IKAPI). 2014

Majid, Abdul.Perencanaan Pembelajaran: Mengembangkan Kompetensi Guru. Bandung: PT Remaja Rosdakarya. 2008 
Prastowo,Andi.Pengembangan Sumber Belajar. Yogyakarta: Pedagogia. 2012

Sagala, Syaiful. Supervisi Pembelajaran dalam Profesi Pendidikan. Bandung: Alfabeta. 2010

Samatowa, Usman. Pembelajaran IPA Di Sekolah Dasar. Jakarta Barat: PT Indeks. 2010

Syarif Sumantri, Mohammad.Strategi Pembelajaran: Teori dan Praktik di Tingkat Pendidikan Dasar. Jakarta: Rajawali Pers. 2015

Yaumi, Muhammad.Prinsip-prinsip Desain Pembelajaran. Jakarta: Kencana. 2013 